\title{
TINJAUAN KONSEP IMAGO DEI IRENAEUS DAN THOMAS DARI PERSPEKTIF YOHANES CALVIN SERTA DAMPAKNYA BAGI ZAMAN PASCA MILLENIAL
}

\author{
Tumpal Hasudungan Hutahaean \\ Gereja Reformed Injili Indonesia Cikarang
}

Korespondensi: hutahaean.tumpal@gmail.com

\begin{abstract}
ABSTRAK: Tujuan penulisan makalah ini adalah untuk mengungkapkan keunikan pemahaman Yohanes Calvin tentang makna Imago Dei sebagai reaksinya terhadap pemahaman para teolog Irenaeus dan Skolastik Abad Pertengahan seperti Aquinas, kemudian memaparkan implikasi Imago Dei secara teologis dalam konteks penciptaan Allah dan signifikasinya di zaman digital berkaitan dengan identitas diri. Calvin mengembalikan pandangan Imago Dei kembali ke pandangan alkitabiah. Dengan tesis, manusia harus memiliki pengetahuan yang benar tentang Tuhan dan diri mereka sendiri. Hanya melalui Yesus Kristus dan firman-Nya manusia dapat diperbarui dan mengenal dirinya sebagai Imago Dei sehingga dapat memuliakan Tuhan lagi. Dan hanya melalui pekerjaan Allah Roh Kudus manusia dapat mencerminkan Allah di dunia ini.
\end{abstract}

KATA KUNCI: Gambar Allah; kerusakan total; penebusan; pembaruan; mengenal diri.

ABSTRACT: This article seeks to express the uniqueness of John Calvin's understanding of the meaning of Imago Dei as his reaction to the understanding of the theologians of Irenaeus and Medieval Scholastic Aquinas, then to explain the implications of Imago Dei theologically in the context of God's creation along with its significance on self-identity in the digital age. Calvin restores Imago Dei's view back to the bible. His thesis is human must have the right knowledge about God and himself. It is only through Jesus Christ and His word can a man be renewed and knows himself as Imago Dei, so that he can glorify God again. And it is only through the work of 
the Holy Spirit can man reflects God in this world.

KEYWORDS: Imago Dei; total depravity; redemption; renewal; knowing oneself.

\section{Pendahuluan}

Pengertian tentang konsep Alkitab mengenai Imago Dei (gambar Allah) telah menjadi sebuah subjek teologis yang sering diperdebatkan dan dipikirkan para teolog Kristen di sepanjang sejarah kekristenan. David Cairns dalam bukunya The Image of God in Man menegaskan bahwa tiada perdebatan yang lebih mendasar di dunia masa kini daripada perdebatan mengenai natur manusia. ${ }^{1}$

Perdebatan di atas terjadi karena konsep Imago Dei hanya mempunyai tiga referensi yang eksplisit dalam Perjanjian Lama. Ketiganya tercatat dalam kitab Kejadian: pertama, mengenai penciptaan manusia (Kejadian 1:26-27); kedua, mengenai penurunan/transmisi gambar Allah kepada keturunan Adam yang bernama Set (Kejadian 5:1,3); dan ketiga, mengenai ancaman terhadap penumpahan darah manusia sebagai gambar Allah (Kejadian 9:6).

\section{Pemikiran Antropologi Irenaeus}

Irenaeus mengatakan bahwa kata "gambar" itu merujuk pada unsur fisik, yakni kebebasan dan akal budi manusia; sedangkan kata "rupa" merujuk pada unsur etis dari gambar ilahi yaitu karunia persekutuan dengan Allah. ${ }^{2}$ Bagi Irenaeus keserupaan manusia dengan Allah telah hilang ketika manusia jatuh di dalam dosa, sedangkan gambar Allah tetap ada. Ia percaya di dalam proses penebusan keserupaan dengan Allah yang hilang akan dipulihkan bagi orang yang percaya kepada Kristus. Seperti yang Irenaeus katakan di dalam buku David Cairns,

Man's likeness to God, however, was lost in the fall, whereas the image of God still remained. However, the lost likeness to God is being restored in believers in the process of redemption. ${ }^{3}$

Dengan hilangnya rupa Allah setelah kejatuhan dalam dosa, maka manusia tetap memiliki jiwa tetapi tidak memiliki roh. Manusia yang berdosa menjadi tidak sempurna, hidup dalam daging dan sifat alamiahnya seperti hewan. Manusia seperti ini tidak akan menerima keserupaan di dalam Kristus. Dalam hal ini manusia memerlukan Roh Kudus untuk memulihkan

\footnotetext{
David Cairns, The Image of God in Man (London: SCM Press Limited, 1953), 9.

Irenaeus, Against Heresies, V.6.1, in Ante-Nicene Fathers, vol. 1, ed. Alexander Roberts and James Donaldson (Grand Rapids: Eerdmans, 1953), 16.

3 David Cairns, The Image of God in Man, 80.
} 
rupa Allah padanya yang telah hilang akibat kejatuhan dalam dosa. ${ }^{4} \mathrm{Bagi}$ Irenaeus rupa Allah itu adalah Roh Kudus yang diberikan kepada Adam namun hilang setelah kejatuhan. Dengan demikian orang yang tidak percaya juga hanya memiliki tubuh dan jiwa, sedangkan rohnya tidak ada.

Bila manusia itu mau sempurna kembali maka ia memerlukan penebusan di dalam Kristus. Bagi Irenaeus, Yesus Kristus merupakan pemulih keadaan manusia yang tidak sempurna dengan pengembalian rupa Allah di dalam diri manusia, dan Yesuslah yang memersatukan kembali manusia dengan Allah sebagai pencipta manusia. ${ }^{5}$

Bagi Irenaeus, gambar Allah yang ada di dalam manusia yakni "naturnya sebagai akal budi (rasio) dan kebebasan tidak hilang pada saat kejatuhan manusia dalam dosa." ${ }^{6}$ Dengan kata lain Irenaeus berpandangan manusia yang sudah berdosa masih memiliki gambar Allah. Pemikiran Irenaeus tentang "gambar" ini dipengaruhi oleh pemikir-pemikir klasik Yunani, seperti Plato, Aristoteles, juga para kaum Stoisisme. ${ }^{7}$

Sedangkan pengertian rupa Allah menurut Irenaeus diartikan sebagai "robe of sanctity," (jubah kekudusan) yaitu Roh Kudus yang diberikan kepada Adam. ${ }^{8}$ Roh yang diberikan kepada Adam sebelum kejatuhan telah hilang oleh karena dosa. Oleh karena itulah Irenaeus percaya bahwa orang percaya memiliki tiga komponen di dalam dirinya yaitu: tubuh, jiwa dan roh; yaitu pandangan Trikotomi. Sementara orang yang tidak percaya hanya memiliki dua komponen di dalam dirinya yaitu tubuh dan jiwa saja. Menurut Irenaeus, Roh Kudus menciptakan roh manusia sebagai suatu organ, yang melaluinya orang percaya menerima pengaruh ilahi dan dapat mengenal kebenaran ilahi. ${ }^{9}$ Roh manusia ini berada di dalam tempat rupa Allah. Adapun pengembalian pada tempatnya ini hanya dapat dipulihkan kembali melalui penebusan Kristus bagi manusia.

\section{Kritik terhadap Pandangan Irenaeus}

Pertama mengenai pandangan Irenaeus yang mengatakan bahwa kejatuhan manusia menyebabkan hilangnya rupa Allah dan tersisanya gambar Allah. Bagi Calvin gambar dan rupa Allah tidak hilang ketika manusia jatuh di dalam dosa, namun rusak secara total. Calvin melihat tidak ada perbedaan

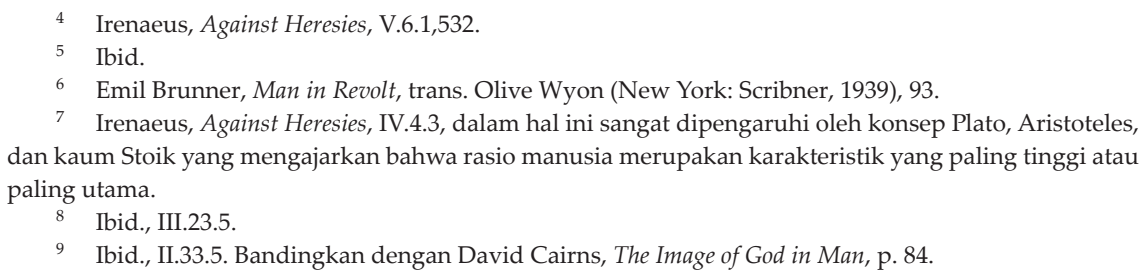


pengertian antara kata "gambar" dan "rupa". ${ }^{10}$ Pengertian Irenaeus yang membedakan kedua istilah ini menunjukkan bahwa ia telah salah menafsirkan. Pandangan Calvin sesuai dengan pandangan Alkitab, bahwa kedua istilah itu dapat dipakai secara bergantian di dalam pengertian yang sama. Sebagaimana yang Alkitab nyatakan di dalam Kejadian 1:26, 27; 5:1; 9:6; 1 Korintus 11:7; Kolose 3:10; Yakobus 3:9. Jadi di Alkitab kedua istilah "gambar" dan "rupa' merupakan sinonim, dan dapat saling ditukar penggunaannya.

Kedua, mengenai pernyataan Irenaeus akan adanya aspek yang bertahan dan yang tidak bertahan dari manusia sebagai gambar Allah setelah kejatuhan di dalam dosa. Aspek yang bertahan setelah kejatuhan adalah rasio (mind). Pandangan ini dipertahankan oleh Irenaeus yang berpendapat bahwa manusia adalah makhluk rasional. Sedangkan aspek yang hilang setelah manusia jatuh di dalam dosa hanyalah rohnya saja.

Calvin tidak setuju dengan pandangan Irenaeus akan kerusakan yang terbatas ini. Menurut Calvin, setelah kejatuhan segala karunia dan kemampuan pada manusia seperti akal budi dan kehendak manusia sudah rusak secara total. Calvin juga mengatakan bahwa semua kemampuan manusia, di dalam keberadaannya yang rusak, nilainya menjadi rendah dan tercemar. Sebagai akibatnya semua tindakannya lebih cenderung jauh dari ketetapan Allah karena semuanya sudah tidak terkendalikan. ${ }^{11}$ Pandangan Calvin ini sesuai dengan pandangan alkitab di dalam Roma 3:10-18 yang menyatakan bahwa manusia sudah rusak total dan bukan rusak terbatas (Total depravity, not limited depravity).

Alkitab menunjukkan kepada kita bahwa setelah kejatuhan di dalam dosa, keberadaan manusia rusak total, termasuk sifat pikirannya (mind), sifat kebenaran-keadilannya (righteousness), dan sifat kesuciannya (holiness). ${ }^{12}$ Sedangkan bagi Irenaeus sesuatu yang terpisah itu tidak merusak atau mengganggu keutuhan manusia sebagai ciptaan Allah di dalam fungsi rasionalitasnya dan kebebasannya. Dalam hal ini Irenaeus salah karena menganggap aspek rasionalitas sebagai hal yang paling utama dari manusia sebagai gambar Allah.

Ketiga, Calvin tidak menerima konsep trikotomi dari Irenaeus karena Alkitab memakai secara sinonim kata jiwa dan roh. Bagi Calvin, gambar Allah pada manusia terletak di dalam jiwa manusia. Namun, walaupun tempat utama dari gambar ilahi ada di dalam hati dan pikiran (mind) atau

10 John Calvin, Institutes, trans. and ed. by John T. McNeill (London: Westminster John Knox press, 2006), I.15.3.

11 Ibid.

12 Ibid. 
di dalam jiwa dan kuasanya, tidak ada satu bagianpun dari manusia yang tidak memancarkan gambar Allah. ${ }^{13}$ Calvin mengatakan bahwa,

For although God's glory shines forth in the outer man, yet there is no doubt that the proper seat of his (God's) image is in the soul. ${ }^{14}$

Konsep Irenaeus tentang trikotomi tidak dapat diterima karena merusak konsep kesatuan Imago Dei. Pemikiran Irenaeus sangat dipengaruhi oleh filsuf Yunani yang melihat manusia dalam keberadaan utamanya yaitu rasionalitasnya (nous); padahal manusia sebagai makhluk yang memiliki rasio juga sekaligus memiliki tubuh yang merupakan material. Lalu untuk mengaitkan kedua hal ini diperlukan realitas ketiga yang berfungsi sebagai mediator (perantara), yaitu jiwa yang oleh fungsi rasio dapat mengarahkan tubuh.

Dalam hal ini, Alkitab tidak pernah membuat antitesis yang tajam antara roh (akal budi) dengan tubuh. Alkitab mengajarkan bahwa tubuh ini tidak jahat karena dicipta oleh Allah. Alkitab melihat bahwa tubuh manusia ini bukan sumber kejahatan; tubuh dicipta Tuhan baik adanya dan harus dipakai untuk melayani Allah. Sebagaimana yang dikatakan Rasul Paulus dalam Roma 12:1-2,

Karena itu, saudara-saudara, demi kemurahan Allah aku menasihatkan kamu, supaya kamu mempersembahkan tubuhmu sebagai persembahan yang hidup, yang kudus dan yang berkenan kepada Allah: itu adalah ibadahmu yang sejati. ${ }^{2}$ Janganlah kamu menjadi serupa dengan dunia ini, tetapi berubahlah oleh pembaharuan budimu, sehingga kamu dapat membedakan manakah kehendak Allah: apa yang baik, yang berkenan kepada Allah dan yang sempurna.

Orang Yunani memiliki pandangan trikotomi karena mereka melihat tubuh ini sebagai penjara jiwa (soma sema) yang akan ditinggalkan dengan sukacita pada saat kematian. Pandangan ini bertentangan dengan Firman Tuhan. Pandangan Irenaeus tentang trikotomi yang menempatkan pembedaan yang tajam antara roh dan jiwa, juga tidak memiliki dukungan Alkitab. Pandangan trikotomi sering mengacu pada dua ayat Perjanjian Baru, Ibrani 4:12 dan 1 Tesalonika 5:23; akan tetapi keduanya sama-sama tidak mendukung.

\section{Antropologi Teolog Skolastik Abad Pertengahan: Aquinas}

Thomas Aquinas mengakui dirinya sebagai pengikut setia dari Agustinus. Namun ada perbedaan utama diantara keduanya, Thomas mengambil kebenaran tentang kekristenan dari pengajaran Agustinus dan menyatakannya 95.

13 John Calvin, Commentaries on the Old Testament: on Genesis, (Grand Rapids: Eerdmans, 1948-1950),

14 Calvin, Institutes, I.15.3. 
dengan terminologi Aristoteles. Sedangkan Agustinus memakai terminologi Plato. Selain itu, tampak juga adanya pergeseran penekanan dimana Thomas lebih menekankan peranan rasio dibandingkan dengan Agustinus. ${ }^{15}$

Oleh karena itulah penulis memilih Thomas Aquinas sebagai tokoh pada Abad Pertengahan yang mewakili Roma Katolik yang berbicara mengenai Imago Dei. Pikiran Thomas tentang natur manusia banyak mempengaruhi ajaran Roma Katolik dimana pemikiran Thomas tentang doktrin manusia menjadi standar gereja Roma Katolik.

Thomas di dalam pandangannya tentang natur manusia melihat bahwa unsur gambar Allah di dalam diri manusia terkandung pada inteleknya saja. Dengan kata lain Thomas menyamakan gambar Allah dengan rasio manusia. Bahkan ia percaya bahwa intelek/rasio tersebut tidak akan punah. Thomas menegaskan bahwa

Image of God is primarily in man's intellect or reason. Only intelligent creatures can, properly speaking, be said to be in God's image. In fact, Thomas continues, the image of God is found more perfectly in angels than in men, because the natures of angels are "more perfectly intelligent" than those of men. Since Thomas finds the image of God particularly in man's intellect, it is clear that for him the intellect is the most God like quality in man. ${ }^{16}$

Lebih jauh lagi Thomas mengatakan bahwa gambar Allah pada manusia terbagi dalam tiga jenjang. Jenjang pertama terdapat di dalam kecerdasan atau bakat manusia untuk mengerti dan mengasihi. Hal ini merupakan isi dari pikiran yang dimiliki semua manusia. Jenjang kedua terdapat di dalam seseorang ketika ia mengenal dan mengasihi Allah, walaupun masih belum sempurna; dalam hal ini gambar tersebut belum dipulihkan. Di jenjang ketiga gambar Allah terdapat di dalam seseorang ketika ia benar-benar mengenal dan mengasihi Allah secara sempurna. Oleh karena itulah Thomas mengatakan bahwa

The form in which the image of God is found in all people is "man's natural aptitude for understanding and loving God..... which is common to all men." Note that Thomas described this first stage of image as an aptitude for rather than, as in the case of the other two stages, an actual understanding and loving of God. The image of God, in other words, is described here in terms of a certain capacity or endowment found in all human pesons, rather than in terms of the type of activity that flows from that endowment. ${ }^{17}$

Jadi Thomas mengakui bahwa gambar Allah "ada" pada setiap manusia

\footnotetext{
15 Norman L. Geisler and Paul D. Feinberg, Introduction to Philosophy (Grand Rapids: Baker Books, 1980), 290.

16 Thomas Aquinas, Summa Theologica, trans. Blackfriars (New York: McGraw Hill, 1980), 93.

17 Ibid., I.12.12.
} 
baik orang yang tidak percaya maupun orang yang percaya. Pemikiran ini mirip dengan pemikiran Irenaeus tentang gambar Allah, tetapi Thomas tidak membedakan pengertian kata gambar dan rupa seperti yang dilakukan oleh Irenaeus. Bagi Thomas tidak ada salahnya jika dalam konteks tertentu menyebutkan gambar dan dalam konteks yang lain menyebutkan rupa. ${ }^{18}$

Thomas juga berpandangan bahwa gambar tersebut mengalami kerusakan karena dosa, dimana manusia kehilangan anugerah supernatural yang Allah berikan kepadanya ketika permulaan penciptaan, namun dalam Kristus gambar tersebut telah dipulihkan. Anugerah supernatural ini berguna untuk penyembuhan, dan juga demi mencapai kebaikan yang bernilai supernatural. ${ }^{19}$ Alasan yang lain mengapa manusia membutuhkan anugerah supernatural/ilahi adalah untuk mencapai kehidupan yang kekal. Manusia tidak dapat berusaha untuk mencapai hasil yang setaraf dengan kehidupan kekal jika ia hanya bergantung pada kuasa natural. Oleh karena itulah diperlukan suatu kuasa yang lebih tinggi, yang disebut dengan kuasa anugerah atau supernatural. Lebih tegas lagi Thomas mengatakan,

A man cannot, by his natural power, produce meritorious works commensurate with eternal life. A higher power is needed for this, namely the power of grace. Hence a man cannot merit eternal life without grace. ${ }^{20}$

Oleh karena itulah bagi Thomas manusia yang telah jatuh dalam dosa tidak mempunyai kemampuan untuk mengontrol kekuatan lemahnya yang dikuasai oleh nafsu dan emosi (lower power) di bawah akal budinya. Jika ingin kembali dapat mengontrol kekuatannya maka manusia perlu anugerah supernatural.

Pemikiran Thomas akan gambar Allah dan konsekuensinya setelah kejatuhan manusia meninggalkan kesan yang dalam bagi para filsuf dan teolog seperti Immanuel Kant, kemudian Schleiermacher, bahkan pandangan tersebut juga masih dianut oleh sebagian teolog masa kini. ${ }^{21}$ Thomas berpandangan bahwa

There is also a sense in which all human beings not only have the aptitude for understanding and knowing God but actually do know God, apart from God's special grace. Thomas answers that, although man apart from God's special grace cannot know God as he is in himself, he can by the natural light of reason know that God is the first and preeminent cause of all things. ${ }^{22}$ Thomas further teaches that man, without the help of grace, can know truth by himself-the truth about such intelligible things as we can learn through the senses. But

18 Ibid., I.93.9.

Ibid., I-II. 164.1.

Ibid., I-II.109.6 (Fairweather trans)

John D. Hannah, Church History (Dallas Theological Seminary: Unpublished Class Note, 1974$), 1$.

Aquinas, Summa Theologica, I.12.12. 
man's intellect "cannot know intelligible things of a higher order unless it is perfected by a stronger light, such as the light of faith or prophecy, which is called 'the light of glory' since it is added to nature." 23

Dari pendapat Thomas ini timbul suatu pertanyaan: dapatkah manusia yang terpisah dari anugerah Allah mengasihi Allah? Thomas menjawabnya,

There is, however, such a things as natural knowledge and love of God....And it is also natural to the mind that it has the power of using reason to understand God, and it was in terms of such a power that we said God's image remains always in the mind. ${ }^{24}$

Jadi bagi Thomas manusia tetap dapat mengenal dan mengasihi Allah yang bersifat natural. Karena baginya pikiran secara natural memiliki kekuatan untuk menggunakan akal budi untuk mengerti Allah karena gambar Allah tetap ada dalam pikiran manusia. Walaupun demikian Thomas mengakui bahwa gambar Allah yang ada dalam pikiran manusia tidak semuanya terang. Karena ada kalanya gambar itu suram, seperti halnya orang yang tidak menggunakan akal budinya. Menurut Thomas gambar Allah yang suram itu ternoda seperti orang berdosa sedangkan gambar Allah yang terang seperti manusia yang dibenarkan. ${ }^{25}$

Bagi Thomas keberadaan manusia sebelum jatuh dalam dosa memiliki daya juang antara akal budi dan kekuatan yang lemah, ${ }^{26}$ sehingga mereka membutuhkan karunia supernatural untuk memampukan mereka mengontrol kekuatan lemah yang dikuasai oleh nafsu dan emosi (lower power) dengan akal budi. Ketika itu akal budi manusia tunduk kepada Allah dan kekuatan lemah tunduk kepada akal budinya dan tubuhnya tunduk kepada jiwanya. Tunduknya tubuh kepada jiwa dan kekuatan lemah (lower power) kepada akal budi bukanlah secara alamiah terjadi tetapi merupakan anugerah Allah semata-mata atau karunia supernatural. ${ }^{27}$

Pandangan Thomas ini sangat memengaruhi pandangan Roma Katolik, natur manusia terutama adalah suatu pemberian secara rasional, sedangkan relasinya dengan Allah adalah suatu tambahan supranatural. Supaya keinginan dan kesabaran manusia bisa tetap terkontrol, maka Allah memberi manusia suatu pemberian ekstra (extra gift) yang kemudian lenyap pada saat kejatuhan manusia. Penambahan ekstra ini disebut kebajikan yang mula-mula dengan tujuan untuk menjaga suatu natur yang lebih rendah di bawah pengendalian. Ini diharapkan membentuk keserupaan 
manusia dengan Allah. ${ }^{28}$ Kata gambar yang tercatat dalam Kejadian 1:26 adalah gambar yang natural. Sedangkan kata rupa merupakan pemberian yang bersifat supranatural.

Pandangan Roma Katolik mengerti bahwa gambar Allah itu hanya merujuk pada unsur rasio, khususnya kehendak hati manusia atau kebebasan kehendak (will) manusia itu sendiri. Mereka membedakan antara gambar Allah dan kebenaran asali (original righteousness) yang dimiliki oleh manusia. Mereka mengatakan bahwa kebenaran asali manusia telah hilang, namun gambar Allah masih ada. ${ }^{29}$

Di dalam konsep yang lain yaitu tentang "Karya Penebusan Yesus Kristus", Thomas mendasarkan pemikirannya pada konsep kemahakuasaan Allah. Bagi Thomas bertolak dari pandangan ini, ia percaya bahwa Allah dapat memperbarui natur manusia dengan banyak cara. Thomas percaya bahwa inkarnasi Kristus dan kematian-Nya di bukit Golgota bukanlah satu-satunya cara untuk memerbarui Imago Dei (rasio) yang rusak karena dosa. Lebih jauh lagi, Thomas mengatakan,

A things is said to be necessary for certain and in two ways. First, when the end cannot be without it as food is necessary for preservation of human life. Secondly, when the end is attained better and more conveniently as a horse is necessary for journey. In the first way it was not necessary that God should become incarnate for restoration of human nature. For God of His Omnipotent power could have restored human nature in many other ways. But in second way, it was necessary that God should become incarnate for the restoration of human nature. ${ }^{30}$

Walaupun Thomas percaya Allah yang Mahakuasa punya banyak cara untuk menyelamatkan umat-Nya, bahkan ia percaya bahwa Allah mungkin membebaskan manusia dari dosa tanpa melalui penderitaan Kristus. ${ }^{31}$ Namun demikian Thomas juga berusaha meyakinkan bahwa penebusan Kristus dengan cara Ia mati di bukit Golgota dan bangkit pada hari yang ketiga adalah cara yang terbaik untuk memerbarui natur manusia yang berdosa. Alasannya karena Thomas melihat aspek dosa hanya dapat diselesaikan melalui pengorbanan Kristus di kayu salib. Penekanan Thomas ini diperkuat dengan pendapatnya,

Hence, since every where in the sacred Scripture the sin of the first man is assigned as the reason of the Incarnation. It is more in accordance with this to say that the work of the Incarnation was ordained by God as remedy for sin,

28 Louis Berkhof, A Summary of Christian Doctrine, 63.

29 Charles Hodge, Systematic Theology, Vol 2, (Grand Rapids: Hendrickson, 1981), 103.

30 Thomas Aquinas, "The Summa Theologica", Great Books of the Western World, Vol 2. ed. Robert M.H, (Chicago: William Benton Pub. Encyclopedia Britannica, Inc. 1986), III.1.2.

31 Ibid., III.46.2. 
so that, had sin not existed, the Incarnation would not have been. And yet the power of God is not have limited to this; even had sin not existed, God could have become Incarnation. ${ }^{32}$

Thomas melihat bahwa kemarahan Allah akibat dosa manusia harus dipuaskan melalui keadilan Allah di Golgota. Bagi Thomas dosa telah mencemari jiwa manusia dan hal ini berdampak pada ketidaksempurnaan orientasi kehendak. Akibatnya kehendak manusia yang sudah berdosa berbalik pada kehendak Allah dan setia pada hal-hal yang bertentangan dengan akal budi dan hukum ilahi. Dan jiwa yang sudah berdosa ini akan senantiasa melarikan diri dari terang akal budi dan terang ilahi, yaitu Firman Tuhan. ${ }^{33}$ Sebagai akibatnya manusia menjadi objek hukuman Allah dan manusia layak untuk menerima hukuman Allah itu. ${ }^{34}$

Untuk mengatasi hukuman ini, Thomas percaya bahwa inkarnasi Kristus adalah jalan untuk pemuasan murka Allah sekaligus jalan keluar untuk pemulihan jiwa manusia yang berdosa. Akibatnya manusia mendapatkan penghapusan hutang hukuman karena sudah dibayar oleh Yesus Kristus. Thomas mengatakan,

Two things are required for the perfect cleansing from sins, corresponding to the two things comprised in sin namely, the stain of sin and debt of punishment. The stain of sin is, indeed, blotted out by grace, by which the sinner's heart is turned to God: Wheareas the debt of punishment removed by the satisfaction that man offers to God. Now the priesthood of Christ produces both these effects. For by its virtue grace is given to us, by which our hearts are turned to God, according to Rome 3:24-25: Being justified freely by His Grace, through the redemption in Christ Jesus, whom God hath proposed to be a propitiation, through faith in His blood. Moreover, He satisfied for us fully, inasmuch as He hath borne our infirmities and carried our sorrows (Isaiah 53:4). ${ }^{35}$

Walaupun Thomas percaya pada pentingnya pengorbanan Kristus di kayu salib untuk memuaskan murka Allah bagi manusia berdosa, namun ia percaya Allah bisa mengampuni manusia tanpa melalui jalan salib. Bagi Thomas, Allah di dalam kemurahan-Nya dan kemahakuasaan-Nya tetap dapat mengampuni manusia berdosa tanpa melalui jalur hukuman akibat dosa. ${ }^{36}$ 


\section{Kritik terhadap Pandangan Thomas Aquinas}

Pertama, Thomas mengerti gambar Allah di dalam manusia itu terletak pada rasionya, dan bukan pada unsur-unsur yang lain dari manusia. Pandangan ini lebih mirip dengan pandangan dari pemikir-pemikir Yunani dibandingkan dengan Alkitab itu sendiri. Jadi secara tidak langsung pemikiran Thomas ini sangat mendukung pemikiran Yunani dan mungkin membuat mereka yakin akan idenya ini. Intelek manusia itu merupakan cerminan dari Allah Yang Maha Tahu, tetapi bila mengatakan bahwa gambar Allah dalam manusia hanya ada di bagian itu saja, berarti pandangan ini lebih condong pada pemikiran Yunani daripada Alkitab. Alkitab tidak pernah menyatakan bahwa Allah adalah intelek melainkan menyatakan Allah yang kasih dan murah hati.

Bagi Calvin, gambar Allah pada manusia terletak di dalam jiwa manusia. Namun menurut Calvin tempat utama dari gambar ilahi adalah di dalam hati dan pikiran (mind), atau di dalam jiwa dan kuasanya, tetapi tidak ada satu bagianpun dari manusia yang tidak memancarkan gambar Allah. ${ }^{37}$ Menurut Calvin kerusakan gambar Allah dalam manusia bersifat total, termasuk juga aspek intelektualnya. ${ }^{38}$

Kedua, pengertian Aquinas tentang keberadaan mula-mula manusia, yang dalam keadaan berjuang antara aspek "lower" dan "higher", dimana aspek "lower" harus dikontrol oleh yang "higher". Pengontrolan ini dapat terjadi jika diberi karunia tambahan yaitu anugerah supernatural. Setelah manusia jatuh di dalam dosa, karunia tambahan yaitu anugerah supernatural hilang, namun natur manusia dalam rasionya tetap baik. Dengan demikian Thomas menyangkali bahwa manusia pada mulanya itu baik adanya dan tidak rusak; bahwa manusia sebagai gambar Allah tidak memerlukan karunia tambahan lagi karena manusia baik adanya di mata Allah (Kejadian 1:31).

Calvin menyetujui bahwa gambar Allah tersebut tidak punah sama sekali, melainkan gambar Allah tersebut telah tercemar, termasuk juga aspek rasio sehingga apa yang masih tertinggal adalah rupa yang buruk dan yang menakutkan. ${ }^{39}$ Ia mengatakan, bahwa pada manusia yang telah jatuh dalam dosa, masih dapat terlihat adanya tanda-tanda gambar Allah, yang membedakan seluruh umat manusia dengan ciptaan lainnya. ${ }^{40} \mathrm{Di}$ 95.

37 John Calvin, Commentaries on the Old Testament: on Genesis, (Grand Rapids: Eerdmans, 1948-1950),

38 Calvin, Institutes, II.2.20.

39 Calvin, Institutes, Vol. 2. trans. Henry Beveridge (Grand Rapids: W.B. Eerdmans Publishing Company, 1972), 12-15.

40 Calvin, Institutes, II.2.17. 
bagian lain Calvin menyebut hal ini sebagai sisa-sisa gambar Allah. ${ }^{41}$ Akal budi dan kehendak masih tetap ada pada manusia setelah jatuh dalam dosa, semua ini bagi Calvin disebut dengan "karunia-natural", yang walaupun tidak hilang, tetapi telah dilemahkan dan dirusakkan oleh dosa. Semua kerusakan gambar Allah ini hanya melalui Yesus Kristus dapat dipulihkan dan tidak ada jalan yang lain. ${ }^{42}$

Ketiga, pengertian Thomas tentang gambar Allah sebelum dan sesudah kejatuhan telah mengurangi keseriusan akibat dosa bagi manusia. Menurut Thomas keberadaan manusia sebelum dan sesudah jatuh dalam dosa hampir sama dasarnya. Perbedaannya hanya pada karunia tambahan. Kejatuhan mengakibatkan manusia kehilangan anugerah itu, yang berarti bahwa keberadaan manusia secara total setelah jatuh dalam dosa tidak rusak total.

Calvin menolak pandangan Thomas ini yang mengartikan kejatuhan sebagai hilangnya bagian tambahan pada natur manusia, yakni karunia tambahan, yang menyebabkan hilangnya keindahan manusia dari sebelumnya. Ia menegaskan bahwa dosa telah merusak dan menodai semua natur manusia dan semua karunianya, sehingga manusia telah mati secara rohani. ${ }^{43}$ Menurut Calvin kerusakan gambar Allah dalam manusia bersifat total, termasuk aspek intelektualnya. ${ }^{44}$ Alkitab menyatakan bahwa setelah jatuh dalam dosa, manusia telah rusak total (band. Roma 3:10-12). Di dalam kitab Mazmur, Daud berkata "Sesungguhnya, dalam kesalahan aku diperanakan, dalam dosa aku dikandung ibuku" (Mazmur 51:5). Dalam hal ini Daud mempertegas bahwa keberadaannya sudah berdosa sejak dalam kandungan, dan orang tuanya-lah yang menurunkan itu semua.

Keempat, ajaran Thomas, yang menyatakan bahwa terjadi pertentangan antara kekuatan lemah yang dikuasai nafsu dan emosi (lower power) dengan akal budi dalam tubuh manusia, telah merendahkan nilai tubuh yaitu keinginan dan emosi dari kedudukannya lebih rendah dari natur manusia yaitu rasio. Penilaian Thomas tentang tubuh lebih diarahkan pada subjek daripada nafsu akal budi. Thomas menyatakan bahwa:

Now all that the virtues are is a set of perfection by which to reason is directed towards God and the lower powers are managed according to the standard of reason..$^{45}$

41 John Calvin, Commentaries on the Old Testament: on Genesis, 296.

42 Calvin, Institutes, II.2.12.

43 John Calvin, Commentaries on John, trans. Parker (Grand Rapids: Eerdmans, 1979), 40.

44 Calvin, Institutes, II.2.20.

45 Thomas Aquinas, Summa Theologica, I. 95.3. (Blackfriars trans) 
Dari pernyataan di atas dapat dilihat bahwa akal budi manusia bagi Thomas selalu benar dan tidak pernah salah. Konsep ini mirip dengan pemikiran Yunani dibandingkan dengan Alkitab sendiri. Pembagian aspek-aspek natur manusia menjadi higher power dan lower power pun menunjukkan suatu dikotomi yang tidak alkitabiah. Alkitab menyatakan bahwa manusia dicipta seutuhnya oleh Allah dan tidak ada aspek yang lebih tinggi dan lebih rendah dari natur manusia.

Dengan pengertian tubuh sebagai tempat lower power yang menjadi sumber dosa dan cara mematikannya adalah dengan cara menindas keinginan tubuh. Pandangan seperti ini pernah terjadi pada Abad Pertengahan, dimana para rohaniawan banyak melakukan selibat karena melihat keinginan tubuh itu jahat, oleh karena itulah hal itu perlu dan sangat penting. Para biarawan dan biarawati menganggap diri mereka rohani jika mereka berhasil menindas atau menyiksa tubuh mereka.

Bagi Calvin puncak pergumulan manusia bukan pada perjuangan antara lower power dengan akal budi, melainkan antara ketaatan dan ketidak-taatan kepada Allah dengan segenap kepribadian (pikiran dan keinginan). Alkitab melihat bahwa tubuh bukan lower power yang harus ditindas atau disiksa melainkan aspek ciptaan Allah yang mulia dan baik yang harus dijaga dan dimanfaatkan untuk melayani Allah (baca Roma 12:12). Kemenangan manusia atas keinginan dosa bukan melalui penyiksaan diri, melainkan karena anugerah Allah semata-mata melalui pekerjaan Allah Roh Kudus dan firman-Nya. ${ }^{46}$ Perjuangan iman di dalam memerangi keinginan daging yang berada di dalam diri manusia adalah kunci kemenangan dengan cara hidup di dalam Roh untuk mengalahkan keinginan daging (1 Yohanes 5:4) dan melalui kuasa firman Tuhan manusia dapat diubahkan (2 Timotius 3:16-17) dan mengalami hidup benar (Roma 1:17). Setiap orang Kristen yang taat akan firman Tuhan, Allah sendiri yang menjamin untuk hidup berkemenangan atas kuasa dosa (1 Yohanes 2:1-6).

Kelima, ajaran Thomas tentang manusia yang telah jatuh dalam dosa dapat mengupayakan kehidupan kekal dengan pertolongan anugerah Allah. Ajaran ini menunjukkan bahwa manusia dengan kekuatannya sendiri dapat memeroleh kehidupan yang kekal. Padahal Alkitab menyatakan bahwa kehidupan yang kekal itu dapat diperoleh karena anugerah Allah semata-mata dan tidak ada peran manusia berdosa di dalamnya (Efesus 2:8-10; Roma 6:23).

Ajaran Thomas ini tidak konsisten karena Thomas mengakui pentingnya kematian Kristus untuk menebus dosa-dosa manusia dan ini cara terbaik

46 Calvin, Institutes, II.2.20. 
yang Allah tetapkan. Namun ia juga percaya bahwa Allah dapat menebus dosa manusia tanpa melalui peristiwa salib, dimana Kristus menderita dan mati di kayu salib untuk memuaskan murka Allah. Menurut Calvin hanya melalui Yesus Kristus dan firman-Nya Imago Dei manusia dapat diselamatkan dan dipulihkan. ${ }^{47}$

\section{Hanya melalui Yesus Kristus dan Firman-Nya Manusia dapat Mengenal Dirinya sebagai Imago Dei}

Allah menetapkan Tuhan Yesus Kristus untuk datang ke dunia dan menyelesaikan masalah keberdosaan manusia dan menyelamatkan umat-Nya. Calvin mengatakan,

Since our inquities, like a cloud cast between us and him, had completely estranged us from the Kingdom of Heaven (cf. Isa 59:2), no man, unless he belonged to God, could serve as the intermediary to restore peace.... The situation would surely have been hopeless had the very majesty of God not descended to us, since it was not in our power to ascend to him, Hence, it was necessary for the Son of God to become for us "Immanuel that is, God with us" (Isa 7:14; Matt 1:23), and in such a way that his divinity and our human nature might by mutual connection grow together. ${ }^{48}$

Selain menekankan peranan Kristus di dalam karya-Nya bagi pemulihan natur manusia, Calvin juga sangat mementingkan peranan Wahyu Khusus sebagai dasar dan pengarah untuk dapat mengenal Allah dengan benar dan membawa pengenalan akan diri dengan benar dan menghasilkan sikap hidup yang benar. Bagi Calvin tidak ada argumen yang betul-betul sempurna untuk membuktikan keberadaan Allah kecuali mengawali semua pengetahuan dari Allah, sehingga dengan itu bisa mengetahui atau mengenal keberadaan Allah. Oleh sebab itu Calvin mengatakan bahwa mengenal Allah, bukan hanya ketika mengerti bahwa Allah ada, tetapi ketika mengerti apa yang benar untuk memahami mengenai Dia dan apa yang menyatakan kemuliaan-Nya. Jadi bagi Calvin, Allah yang sejati tidak mungkin dapat dikenal berdasarkan pengertian rasio manusia. Dengan kata lain mengenal Tuhan tidak mungkin dibangun dari bawah ke atas dan sebaliknya harus dari atas ke bawah. Jadi pengetahuan yang orang percaya miliki tentang Allah mengajar untuk mengharapkan segala yang baik dari-Nya dan memberikan puji-pujian kepada-Nya. Pengenalan akan Allah bukanlah pengetahuan yang abstrak yang bisa dideduksi dengan pemikiran para filsuf melainkan pengenalan tentang siapa Allah di dalam

47 Calvin, Institutes, I.15.3.

48 Ibid. 
relasi sebagai gambar Allah. ${ }^{49}$

Calvin menjelaskan bahwa pengetahuan manusia tentang Allah sebatas Allah sebagai Pencipta dimana manusia sebagai ciptaan (Imago Dei). Manusia sebagai gambar Allah tidak akan pernah mengenal Allah secara sempurna karena manusia adalah ciptaan dan Allah adalah Pencipta yang sempurna. Termasuk juga dengan pandangan-pandangan tentang Allah yang dibangun oleh manusia tidak ada yang sempurna karena rasio manusia yang terbatas dan Allah Pencipta yang tidak terbatas. Dalam bagian ini Calvin percaya akan peranan Alkitab sebagai sumber satu-satunya untuk manusia mengenal Tuhan dan dirinya dengan benar sebagai peta dan teladan-Nya. Berkenaan dengan Alkitab sebagai sumber pengenalan akan Allah dan manusia, Calvin berkata bahwa, "Scripture is needed as guide and teacher for anyone who would come to God the Creator." ${ }^{50}$ Calvin juga mengatakan, "Scripture has its authority from God, not from the Church." ${ }^{11}$ Melalui kalimat di atas jelas sekali bahwa Calvin sangat menjunjung tinggi otoritas Alkitab yang menjadi penuntun untuk mengenal kebenaran yang sejati tentang Allah dan manusia.

Walaupun pengetahuan tentang Allah bisa didapat melalui wahyu umum yaitu alam semesta, tetapi hal itu tidaklah cukup tanpa penyataan khusus dari Allah melalui firman-Nya. Hal ini karena Alkitab memiliki otoritas dari dirinya sendiri dan bukan hasil formulasi dari gereja. Ini berarti gereja di dalam membangun pengertiannya akan Allah dan manusia harus kembali kepada Alkitab. Calvin berpendapat bahwa

For Christian church was from the beginning founded upon the writings of the prophets and the preaching of the apostles, wherever this doctrine is found, the acceptance of it without which the church itself would never existed-must certainly have preceded the church. Scripture exhibits fully as clear evidence of its own truth as white and black things do of their color, or sweet and bitter things do of their taste. ${ }^{52}$

Bagi Calvin agar manusia dapat mengenal dirinya dan mengenal Allah, manusia harus mendekati Firman Tuhan dengan hati yang baru sebagai murid kebenaran.

\section{Hanya melalui Pekerjaan Roh Kudus Manusia sebagai Imago Dei dapat Menjadi Cerminan Allah di Dunia (Agen Moral)}

Calvin di dalam bukunya mengatakan bahwa manusia hanya dapat

49 Calvin, Institutes, I.15.3.

$50 \quad$ Ibid., I.6.1.

51 Ibid., I.7.1.

52 Ibid. 
menyerupai Allah dalam sifat hakikinya yang spiritual dan rasional. Calvin berpandangan bahwa manusia diciptakan menurut gambar Allah (Kejadian 1:26), dan di dalam manusia, Sang Pencipta merasa puas menikmatinya, laksana melihat kemuliaan-Nya sendiri dalam sebuah cermin. Selanjutnya Calvin menegaskan bahwa gambar Allah dikandung dalam kebenaran dan kesucian, sehingga semakin manusia rindu untuk mendekat kepada Allah, maka gambar Allah itu akan semakin nyata dalam diri manusia. Seperti halnya dengan cermin, hanya pada saat cermin itu merefleksikan objek, baru terlihat gambar yang sesungguhnya.

Calvin menyetujui bahwa gambar Allah tersebut tidak punah sama sekali, melainkan gambar Allah tersebut telah tercemar, sehingga apa yang masih tertinggal adalah rupa yang buruk dan yang menakutkan. ${ }^{53}$ Ia mengatakan, bahwa manusia yang telah jatuh dalam dosa, masih dapat melihat adanya tanda-tanda gambar Allah, dan hal ini yang membedakan seluruh umat manusia dengan ciptaan lainnya. ${ }^{54}$ Di bagian lain Calvin menyebut hal ini sebagai sisa-sisa gambar Allah. ${ }^{55}$ Akal budi dan kehendak masih tetap ada pada manusia setelah jatuh dalam dosa, semua ini bagi Calvin disebut dengan "karunia-natural", yang walaupun tidak hilang, tetapi telah dilemahkan dan dirusakkan oleh dosa..$^{56}$

Kerusakan total gambar Allah dalam manusia hanya dapat dipulihkan melalui pembaruan yang bukan karena usaha sendiri melainkan karena anugerah Allah semata-mata yang dinyatakan melalui pekerjaan Roh Kudus melalui Firman-Nya. Lebih tegas lagi Calvin berpendapat bahwa

Imago Dei (Image of God) is essentially a reflection in and by the soul of the Word of God which is itself the lively or quickening image of God. Therefore man has been made such that it is his "special duty to give ear to the Word of God"; while, on the other hand, it is the work of the Holy Spirit who with a wondrous and special energy forms the ear to hear, and the mind to understanding. ${ }^{57}$

Pekerjaan Roh Kudus ini nyata melalui respons iman manusia kepada Firman Allah yang hanya dapat terjadi karena pekerjaan Roh Kudus di dalam hati manusia. Pembaruan gambar Allah itu akan disempurnakan dengan iman dan ini terjadi dengan progresif. Sesuai dengan pendapat Calvin:

\footnotetext{
Calvin, Institutes, Vol. 2. trans. Henry Beveridge (Grand Rapids: Eerdmans, 1972), 12-15.

Calvin, Institutes, II.2.17.

John Calvin, Commentaries on the Old Testament: on Genesis, 296.

Calvin, Institutes, II.2.12.

Ibid., II.2.20.
} 
The manner of the Spirit's working in the elect is that he creates faith in our hearts, so that the image of God, which had been effaced by sin, may be stamped anew upon us, and that the advancement of this restoration may be continually going forward in us during our whole life, because God makes his glory shine forth in us by little and little (Comm. on II Cor 3:18). ${ }^{58}$

Pembaruan gambar Allah ini adalah tujuan dari kelahiran baru, dimana hal itu meliputi pengetahuan, kebenaran dan kesucian. ${ }^{59}$ Pembaruan gambar Allah ini berarti penyesuaian diri pada Kristus sebagai gambar yang sempurna. ${ }^{60}$ Tujuan pembaruan gambar Allah ini adalah agar manusia dapat kembali memancarkan kemuliaan Allah. ${ }^{61}$

Bagi Calvin, pembaruan ini merupakan hasil kerja sama antara anugerah Allah dengan tanggung jawab manusia. Memang Roh Kudus bekerja memperbarui orang percaya dengan Firman, tetapi manusia yang telah dijamah (dimampukan) Roh Kudus juga harus memberi respons kepada Firman dengan iman. Peristiwa ini merupakan reaksi manusia kepada kebenaran Firman Tuhan dan merupakan komunikasi dengan Firman Tuhan. ${ }^{62}$ Dengan demikian dalam pemikiran Calvin terdapat dua faktor yang penting yang membentuk gambar Allah. Pertama adalah tindakan Allah yang merupakan anugerah kepada manusia berdosa. Kedua adalah tanggung jawab manusia untuk memberi respons dengan iman dan semua ini terjadi seiring di dalam doktrin tentang gambar Allah. ${ }^{63}$

Pemikiran Calvin bahwa hanya melalui pekerjaan Allah Roh Kudus fungsi Imago Dei dapat dipulihkan dan pemulihan ini akan memampukan manusia untuk hidup sesuai dengan gambar Allah yang sejati dalam Yesus Kristus (Roma 8:28-29). ${ }^{64}$ Pemikiran Calvin ini juga memengaruhi teolog Reformed selanjutnya, seperti Berkhof yang mengatakan bahwa

The natural and the moral image of God. The former is the broader of the two, and is generally said to consist in man's spiritual, rational, moral, and immortal being. This was obscured but not lost by sin. The latter is the image of God in the more restricted sense, and consists in true knowledge, righteousness, and holiness. This was lost by sin and is restored in Christ, Eph 4:24; Col 3:10. Since man retained the image in the broader sense, he can still be called the image or image bearer of God, Gen 9:6; I Cor 11:7; 15:49; Jas 3:9. ${ }^{65}$

\footnotetext{
58 David Cairns, The Image of God in Man, 150.

59 Calvin, Institutes, I.15.4.

60 Ibid.

61 T.F. Torrance, Calvin's Doctrine of Man (London: Lutterworth, 1949), 79. Bandingkan dengan Institutes,

62 John Calvin, Commentaries on the New Testament, ed. David W. Torrance dan Thomas F. Torrance (Grand Rapids: Eerdmans, 1963-73), 57. Lihat Calvin Commentary on John 17:17.

63 Ibid., 68.

64 Calvin, Institutes, II.12.1.

65 Louis Berkhof, A Summary of Christian Doctrine (Grand Rapids: Eerdmans, 2000), 64.
} II.3.4. 
Walaupun manusia memiliki potensi untuk menjadi baik dan bermoral, tetapi hal itu tetap kurang karena dosa-dosa tidak diselesaikan. Cara penyelesaiannya adalah melalui pekerjaan Allah Roh Kudus dan firman-Nya manusia akan dapat menjadi agen moral, kebaikan dan penebusan.

\section{Signifikansi Konsep Imago Dei menurut Calvin di Zaman Pasca Milenial}

Mengenal diri dan membangun identitas diri di zaman pasca milenial ini semakin sulit karena derasnya arus informasi selama dua puluh empat jam yang terus mengalir dengan inovatif dan adanya tawaran-tawaran kenikmatan hidup seperti film, game, berita, musik, dan lain sebagainya. Seiring dengan berjalannya waktu kemajuan teknologi semakin canggih dan dengan memanfaatkan fasilitas internet semua sudah bisa. Kehadiran internet ini dan dikuti dengan kemajuan teknologi hanya dimanfaatkan untuk tujuan pemenuhan kebutuhan melalui media sosial dari pada membangun jati diri. ${ }^{66}$ Semua ini terbuka untuk semua orang untuk bisa mengaksesnya melalui smartphone dan gadget. Akibat hal ini dapat mengakibatkan kecanduan digital dengan efek samping seperti kecemasan, depresi, penurunan fisik, kesehatan mental, hubungan interpersonal, dan penurunan kinerja ${ }^{67}$ Bagi Calvin manusia tidak mungkin mengenal dirinya dan membangun dirinya jika hanya mengandalkan pengertian rasionya sendiri. Karena rasio manusia sudah berdosa dan terbatas. ${ }^{68}$ Pemikiran Calvin tentang Imago Dei di zaman milenial ini memiliki signifikasi, yang akan diurai di bawah ini.

\section{Pentingnya Mengenal Diri di Hadapan Tuhan dengan Benar di Zaman Digital}

Mengapa Calvin sangat menekankan pentingnya mengenal diri dengan tepat di hadapan Allah? Karena bagi Calvin, seperti apa definisi tentang dirinya sendiri seperti itulah cara manusia memandang tentang kebenaran Allah. Bagi Calvin pengetahuan akan Allah dan diri sendiri bagaikan dua sisi koin yang tidak bisa dipisahkan, karena masing-masing memiliki substansi yang saling terkait satu sama lain. Calvin mengatakan "The knowledge of God that of ourselves are connected," kedua bagian ini terjalin satu dengan lainnya karena tidak ada seorangpun yang dapat mengenal dirinya sendiri

66 Soliha, Tingkat Ketergantungan Pengguna Media Sosial dan Kecemasan Sosial (Semarang -Undip: Interaksi, 2015), 1-10.

67 Ybarra, Alexander, and Mitchell, Depressive Symptomatology, Youth Internet Use, and Online Interactions (California: Adolescent Health, 2005), 9-18; Yen, Chou, Liu, Yang, and Hu, The Association of Internet Addiction Symptoms with Anxiety, Depression (Hertfordshire: Comprehensive Psychiatry, 2014), 1601-1608.

68 Calvin, Institutes, I.15.3. 
jika tidak mengarah pikirannya kepada Allah. ${ }^{69}$ Bagi Calvin "[n]early all the wisdom we possess, that is to say, true and sound wisdom, consists of two part: the knowledge of God and of ourselves." 70

Sesungguhnya setiap manusia telah dikaruniakan benih ilahi untuk mengetahui tentang Tuhan "The knowledge of God has been naturally implanted in the minds of men," dalam hal ini pengetahuan yang dapat manusia miliki hanya sebatas pengetahuan biasa saja dan tanpa iman. ${ }^{71}$ Pengetahuan tentang Allah ini tidak menyelamatkannya karena tidak mengandung pengertian tentang Kristus sebagai Tuhan dan Penebus.

Manusia sering melupakan Tuhan sebagai Pencipta dan Penguasa akan alam semesta ini hanya karena memandang dunia ini sudah ada pada keberadaannya dan Allah bukan sebagai Pencipta. Bagi Calvin pandangan seperti ini berusaha menyingkirkan Allah sebagai Pencipta dan hal ini dikarenakan kesombongan manusia sebagai pemberontak. Lebih jauh Calvin mengatakan "but man turns ungratefully against God."72

Zaman digital telah memengaruhi banyak orang untuk menyombongkan dirinya. Hal ini teridentifikasi melalui hasrat orang milenial untuk aktualisasi diri melalui swafoto atau foto narsisis dan mencari pujian diri melalui media sosial tanpa Tuhan dipermuliakan. Pengenalan akan diri yang salah di zaman digital telah membuat manusia berlomba untuk aktualisi diri dengan bebas di media sosial, baik melalui media foto dan tulisan. Swafoto telah menjadi barometer untuk menyatakan siapa diri dan nilai diri seseorang kepada teman-temannya atau kepada dunia media sosial. Unggahan hasil foto dapat menggambarkan bahwa orang itu butuh perhatian dan pengakuan dari orang lain. Bolehkah orang Kristen memamerkan aktivitas kehidupannya atau aktivitas rohaninya melalui swafoto dan terus diunggah ke dunia media sosial? Dalam bagian ini masalahnya bukan soal swafoto yang membuat seseorang berdosa karena kesombongan, melainkan tujuan atau motivasinya mengunggah itu untuk apa? Jika seseorang melakukan swafoto untuk peninggian diri atau supaya menjadi orang terkenal dan sampai kecanduan untuk mendapatkan pujian (like), maka jelas ini adalah dosa kesombongan. Manusia sebagai Imago Dei terpanggil untuk membesarkan Tuhan (Yohanes 3:30) dan bukan untuk membesarkan dirinya sendiri (bandingkan dengan Matius 23:11).

Bagaimana solusi untuk mereka yang sudah salah dalam mengenal diri dan aktualisasi diri di media sosial? Penyelesaian masalah ini bukan

\footnotetext{
9 Ibid., I.1.1.

Ibid.

71 Ibid., I.3.1.

72 Ibid., I.5.4.
} 
di masalah lower power yang menjadi sumber dosa ${ }^{73}$ dan cara menyelesaikannya bukan dengan mematikan keinginan untuk swafoto. Swafoto bisa baik jika tujuannya untuk dokumentasi. Bagi Calvin puncak pergumulan manusia bukan pada perjuangan antara lower power dengan akal budi, melainkan antara ketaatan dan ketidak-taatan kepada Allah dengan segenap kepribadian (pikiran dan keinginan). Alkitab melihat bahwa tubuh bukan lower power yang harus ditindas atau disiksa melainkan aspek ciptaan Allah yang mulia dan baik yang harus dijaga dan dimanfaatkan untuk melayani Allah (baca Roma 12:1-2). Kemenangan manusia atas keinginan dosa bukan melalui penyiksaan diri, melainkan karena perjuangan iman dan anugerah Allah semata-mata melalui pekerjaan Allah Roh Kudus dan firman-Nya. ${ }^{74}$ Artinya perjuangan iman dalam memerangi keinginan daging dalam diri manusia adalah kunci kemenangan hidup di dalam Roh untuk mengalahkan keinginan daging (1 Yohanes 5:4) dan melalui kuasa firman Tuhan manusia dapat diubahkan (2 Timotius 3:16-17) dan mengalami hidup benar (Roma 1:17). Setiap orang Kristen yang taat akan firman Tuhan, Allah sendiri yang menjamin untuk hidup berkemenangan atas kuasa dosa (1 Yohanes 2:1-6).

\section{Membangun Identitas Diri di Zaman Milenial}

Bagi Calvin, Allah adalah pusat dari segala-galanya, untuk manusia mengenal dirinya dan membangun jati dirinya sebagai Imago Dei. Tidak seorangpun dapat melihat keberadaan dirinya sendiri tanpa mengaitkannya dengan pemikiran-pemikiran atau perenungan tentang Allah. Terminologi berpikir Calvin ini menjelaskan bahwa manusia tidak pernah mencapai suatu pengetahuan yang jelas tentang dirinya sendiri kecuali ia terlebih dahulu melihat kepada wajah Allah dan kemudian turun ke dalam perenungan tentang Tuhan untuk meneliti dirinya sendiri. ${ }^{75}$ Tanpa kesalehan hidup tidak mungkin seseorang dapat mengenal Allah. Lebih jauh lagi Calvin menegaskan bahwa

For until men recognize that they owe everything to God, that they are nourished by his fatherly care, that he is the Author they will never yield him willing service. Nay, unless they establish their complete happiness in him, they will never give themselves truly and sincerely to him. ${ }^{76}$

Calvin menekankan pengenalan akan Allah melalui Yesus Kristus menjadi dasar atau yang pertama, untuk manusia mengenal dirinya dan membangun

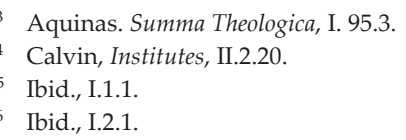


jati dirinya. ${ }^{77}$ John Frame berpendapat bahwa Calvin mengakui bahwa pengetahuan akan Allah melalui Yesus Kristus merupakan satu perspektif yang penting untuk mengenal diri dan membangun diri untuk dapat memahami seluruh Alkitab, bermanfaat untuk menyimpulkan seluruh berita Alkitab serta menjadi kunci khusus untuk mengerti pengajaran Alkitab secara menyeluruh untuk keberartian hidup. ${ }^{78}$

Zaman milenial identitas diri dibangun berdasarkan popularitas di media sosial, barang-barang bermerek, jabatan, dan lain sebagainya. Pencarian jati diri dengan cara demikian akan berujung pada depresi hidup, kekosongan jiwa dan kehilangan makna hidup. Oleh karena itu pengenalan diri dan membangun jati diri yang sejati penting di zaman digital ini.

Zaman sekarang adalah zaman penikmat hidup tanpa Kristus. Zaman digital adalah zaman yang membuat generasi baru tanpa identitas di dalam Kristus. Zaman sekarang disebut generasi pasca milenial yaitu generasi yang lahir dimana teknologi komunikasi - internet dan digital sudah berkembang sangat cepat dan mereka menjadi penikmat perkembangan teknologi smartphone (gadget) dengan leluasa. Kedekatan generasi pasca milenial dengan media sosial dengan segala sarana internet, aplikasi di gadget mengakibatkan generasi digital sekarang ini lebih cenderung untuk independen dalam berpikirnya untuk mengenal diri dan mengenal Tuhan. Hal ini bisa terlihat ketika generasi digital mengambil keputusan berkaitan dengan dirinya, masa depannya, dan lain sebagainya. Mereka lebih mengandalkan informasi-informasi dari internet dan relasi media sosialnya. Pada akhirnya semua keputusan berasal dari buah pikirannya sendiri, tanpa melibatkan Tuhan, ataupun orang tua. Generasi pasca milenial atau generasi digital sekarang ini lebih cenderung menekankan aktualisasi diri di media sosial dibandingkan dengan mengenal diri di dalam Tuhan Yesus Kristus.

Walaupun di media sosial ada info-info tentang pengajaran Tuhan Yesus, siapa yang menjamin jika pengajaran tentang Tuhan itu benar untuk membangun pengenalan akan diri seseorang di dalam Tuhan Yesus? Mungkinkah melalui media sosial hanya berisi tentang pengertian manusia tentang Tuhan yang berasal dari dirinya sendiri? Maka ada spekulasi-spekulasi rasional tentang eksistensi atau natur Allah. Dan apa yang kita pikirkan tentang Allah, yang berasal dari diri kita sendiri. Bagi Calvin ini hanyalah sebuah kebodohan karena berasal dari pemikiran sendiri dan semua yang dapat kita katakan tentang Dia adalah tanpa isi. ${ }^{79}$ Di sinilah perbedaan

Ibid., II.1.1.

78 John M. Frame, Doktrin Pengetahuan tentang Allah, (Malang: SAAT, 2004), 8.

79 Francois Wendel, Calvin-Asal usul dan Perkembangan Pemikiran religiusnya (Surabaya: Momentum, 2010), 163. 
yang sangat menyolok antara pandangan Calvin dengan Thomas tentang akal budi. Bagi Thomas akal budi atau pemikiran manusia selalu benar dan tidak pernah salah. ${ }^{80}$ Faktanya peran rasio dalam mengembangkan teknologi informasi dan digital sangat luar biasa, lebih cenderung menjauhkan manusia dari Tuhan dan firman-Nya. Orang Kristen harus terlibat dalam pengembangan arus teknologi informasi dan digital ini. Kekristenan tidak boleh terdiam dan membiarkan pengetahuan berkembang tanpa pengertian tentang Tuhan Yesus. Oleh karena itu bagi Calvin pikiran manusia harus dikembalikan pada Tuhan Yesus sebagai penciptanya dan pikiran manusia yang sudah berdosa, hanya melalui Yesus Kristus mendapatkan pembaruan dan dapat kembali mencapai pikiran Tuhan (Filipi 4:8). ${ }^{81}$

Calvin menekankan peranan Kristus di dalam karya-Nya bagi pemulihan natur manusia. Calvin juga sangat mementingkan peranan Wahyu Khusus sebagai dasar dan pengarah untuk dapat mengenal Allah dengan benar dan membawa pengenalan akan diri dengan benar dan menghasilkan sikap hidup yang benar. Bagi Calvin tidak ada argumen yang betul-betul sempurna untuk membuktikan keberadaan Allah kecuali mengawali semua pengetahuan dari Allah di dalam Yesus Kristus. Oleh sebab itu Calvin mengatakan bahwa mengenal Allah, bukan hanya ketika mengerti bahwa Allah ada, tetapi ketika mengerti apa yang benar untuk memahami mengenai Dia dan apa yang menyatakan kemuliaan-Nya. Jadi bagi Calvin, Allah yang sejati tidak mungkin dapat dikenal berdasarkan pengertian rasio manusia saja. Pengenalan manusia akan Allah dan dirinya sebagai Imago Dei bukanlah pengetahuan yang abstrak yang bisa dideduksi dengan pemikiran para filsuf melainkan pengenalan tentang siapa Allah di dalam relasinya sebagai gambar Allah. ${ }^{82}$

Membangun identitas jati diri di zaman digital yang rusak ini memang bukanlah sesuatu yang mudah. Setiap manusia di dalam Tuhan perlu mengakui perlunya Tuhan, untuk fungsi hati nuraninya agar bisa memilih antara yang baik dan yang jahat di tengah derasnya arus informasi melalui gadget dan media sosial. Calvin melihat bahwa fungsi dasar hati nurani adalah sebuah kesadaran yang ada di dalam diri manusia untuk membedakan yang baik dan yang jahat, sehingga manusia memiliki kemampuan untuk memutuskan apa yang harus diperbuatnya. ${ }^{83}$ Selain itu hati nurani mer-

\footnotetext{
Aquinas. Summa Theologica, I. 95.3.

Calvin, Institutes, I.15.3.

Ibid., I.15.3.

83 Antara kebebasan dan tanggung jawab manusia sebelum jatuh dalam dosa dan setelah jatuh dalam dosa sangat berbeda kwalitasnya. Kejatuhan manusia di dalam dosa mengakibat jiwa dan pikiran (hati nurani) tidak mampu lagi membedakan mana yang jahat, mana yang salah. (Calvin, Institutes, I.15.8). Melalui anugerah Allah di dalam Yesus Kristus manusia dapat kembali mengendalikan segala keinginannya.
} 
upakan tanda ikatan yang tidak terpisahkan antara ciptaan dan Pencipta dan juga sebuah tanda dari kekekalan jiwa manusia. ${ }^{84}$ Kesadaran tentang penghakiman Allah menjadi saksi yang memperlihatkan kepada manusia amat jelas baik diri-Nya maupun kerajaan-Nya yang diberikan kepada mereka dan yang tidak membiarkan mereka menyembunyikan dosa-dosa mereka, tetapi menyatakan mereka bersalah di depan mimbar pengadilan Sang Hakim ${ }^{85}$.

\section{Kesimpulan}

Calvin tidak melihat adanya perbedaan pengertian antara kata "gambar" dan "rupa". Ia tidak setuju dengan pendapat yang mengatakan bahwa kejatuhan manusia menyebabkan hilangnya rupa Allah dan tersisanya gambar Allah, seperti pandangan Irenaeus dan Thomas. Bagi Calvin yang terjadi adalah segala karunia dan kemampuan yang ada pada manusia seperti akal budi dan kehendak manusia sudah rusak total setelah kejatuhan. Calvin mengatakan bahwa semua kemampuan manusia, di dalam keberadaannya yang rusak, nilainya menjadi rendah dan tercemar sehingga semua tindakannya lebih cenderung jauh dari ketetapan Allah karena semuanya sudah tidak terkendalikan.

Calvin juga menolak pandangan Thomas yang mengartikan kejatuhan sebagai hilangnya bagian tambahan pada natur manusia, yakni karunia tambahan, yang menyebabkan hilangnya keindahan manusia dari sebelumnya. Calvin juga menentang pendapat yang menyatakan bahwa rupa Allah terdapat di dalam kekuasaan manusia atas bumi yang diberikan kepadanya.

Calvin menegaskan bahwa dosa telah merusak dan menodai semua natur manusia dan semua karunianya, sehingga manusia telah mati secara rohani. Bagi Calvin, gambar Allah pada manusia terletak di dalam jiwa manusia. Namun demikian, menurutnya walaupun tempat utama dari gambar ilahi adalah di dalam hati dan pikiran (mind), atau di dalam jiwa dan kuasanya, tetapi tidak ada satu bagian pun dari manusia yang tidak memancarkan gambar Allah.

Calvin percaya jika manusia memiliki hikmat berarti manusia seharusnya memiliki pengetahuan yang benar tentang Allah dan diri sendiri. Calvin percaya bahwa Allah adalah Allah yang bijaksana dan setiap ketetapan-Nya tidak mungkin bertentangan dengan hikmat-Nya dan karakater-Nya sendiri. Manusia dapat melihat dirinya sebagai Imago Dei hanya melalui pengenalan

(Calvin, Institutes, II.3.1).

84 Lucas Lukito, “500 Tahun Yohanes Calvin: Pengetahuan Tentang Allah adalah Testing Ground Untuk Mengenal Manusia" Vol. 10, No. 1. Veritas-Jurnal Teologi dan Pelayanan, 2009, 23.

85 Ibid., 16. 
akan Allah dan mengalihkan pemikiran-pemikirannya kepada perenungan tentang Allah.

Calvin juga menekankan peranan Yesus Kristus di dalam karya-Nya bagi pemulihan natur manusia yang berdosa. Dalam bagian ini Calvin sangat mementingkan peranan Wahyu Khusus sebagai dasar dan pengarah untuk dapat mengenal Allah dengan benar dan membawa pengenalan akan diri dengan benar dan menghasilkan sikap hidup yang benar. Tanpa pengenalan yang benar tentang Allah manusia tidak mungkin dapat menjadi saksi Tuhan yang hidup di dunia ini. Bagi Calvin walaupun manusia memiliki potensi menjadi baik dan bermoral, tetapi hal ini masih kurang karena dosadosanya yang belum diselesaikan. Hanya melalui kuasa penebusan Yesus Kristus manusia akan dapat menjadi agen moral, kebaikan dan penebusan.

Keunikan konsep imago Dei Calvin memiliki signifikansi di zaman pasca milenial ini. Calvin sangat menekankan pentingnya mengenal diri dengan tepat di hadapan Allah, melalui firman-Nya. Menurut Calvin dunia akan selalu berusaha menyingkirkan Allah sebagai Pencipta, sebagai bentuk kesombongan dan pemberontakan manusia. Zaman digital telah sangat berperan dalam membentuk manusia yang sombong dengan dirinya, melalui swafoto atau tulisan di media sosial dengan bebas. Bagi Calvin penyelesaian masalah ini bukan dengan cara mematikan keinginan. Kemenangan manusia atas keinginan dosa bukan melalui penyiksaan diri melainkan melalui perjuangan iman dalam memerangi keinginan daging (1 Yohanes 5:4, 2 Timotius 3:16-17, dan Roma 1:17). Setiap orang Kristen yang taat akan firman Tuhan, ia akan berkemenangan atas kuasa dosa (1 Yohanes 2:1-6). 